\title{
Origins and Evolution of Social Medicine and Contemporary Social Medicine in Korea
}

\author{
Dal Sun Han', Sang-Soo Bae ${ }^{1,2}$, Dong-Hyun Kim ${ }^{1,3}$, Yong-jun Choi ${ }^{1,2}$ \\ ${ }^{1}$ Department of Social and Preventive Medicine, Hallym University College of Medicine, Chucheon; ${ }^{2}$ Health Services Research Center, Hallym \\ University, Chucheon; ${ }^{3}$ Research Institute of Clinical Epidemiology, Hallym University, Chucheon, Korea
}

Social medicine is recognized as one of medical specialties in many countries. However, social medicine has never been formally introduced to Korea, presumably because the term and its principles were not accepted for some years in the past in American medicine, which has strongly influenced Korean medicine. This paper describes the origins and evolution of social medicine and briefly discusses contemporary social medicine in Korea. Social medicine was initiated in France and Germany in 1848. Since then, it has expanded globally and developed in diverse ways. Included in core principles of social medicine is that social and economic conditions have important effects on health and disease, and that these relationships must be subjected to scientific investigation. The term 'social medicine' is rarely used in Korea, but many of its subject matters are incorporated into preventive medicine which, besides prevention, deals with population health that is inescapably social. However, the Korean preventive medicine directs little attention to the basic concepts and principles of social medicine, upon which systematic development of social medicine can be based. Thus, it is necessary to supplement the social medicine contents of preventive medicine through formalizing the linkages between the two fields. One way of doing so would be to change the title of 'preventive medicine' course in medical colleges to 'preventive and social medicine,' as in many other countries, and to adjust the course contents accordingly.

Key words: Social medicine, Preventive medicine, History, Republic of Korea

Received: November 6, 2016 Accepted: April 16, 2017

Corresponding author: Dal Sun Han, MD, DrPH

1 Hallymdaehak-gil, Chuncheon 24252, Korea

Tel: +82-33-248-2660, Fax: +82-33-256-1675

E-mail: dshan01@hanmail.net

This paper is based on the presentation on "an overview of social medicine" delivered at a conference held by the Health Services Research Center, Hallym University on November 26, 2014.

This is an Open Access article distributed under the terms of the Creative Commons Attribution Non-Commercial License (http://creativecommons.org/licenses/by$\mathrm{nc} / 4.0 /$ ) which permits unrestricted non-commercial use, distribution, and reproduction in any medium, provided the original work is properly cited.

\section{INTRODUCTION}

Social medicine course is offered at many medical schools in European countries [1]. Some medical schools in the US have an academic department named social medicine or social medicine in combination with another discipline, such as the Department of Global Health and Social Medicine at Harvard University Medical School, the Department of Family and Social Medicine at the Albert Einstein College of Medicine, and the Department of Social Medicine at the University of North Carolina at Chapel Hill Medical School. And there are medical schools that have the Department of Preventive and Social 
Medicine in numerous countries, including New Zealand, Malaysia, Thailand, Myanmar and India. The first edition of The Social Medicine Reader, edited by the faculty members of the Department of Social Medicine at the University of North Carolina at Chapel Hill Medical School, was published in 1997 [2], and the second edition, published in 2005, was expanded into three volumes [3-5]. These facts indicate that social medicine is recognized as a specialty of medicine in many countries.

In Korea, however, the medical community seems to be hardly aware of that there is a medical specialty named social medicine. A paper on an overview of the historical development of social medicine in the 19th-century Germany is the only published material about social medicine written in Korean [6]. The fact that the Korean medical community is not aware of social medicine does not imply that nothing about social medicine is dealt with in the medical schools or none of the approaches based on social medicine is employed in the health care system. The evolution of social medicine has been internationally diverse, so that its concerns and subject matters may vary to some extent among different national contexts [7]. Based upon these observations, this paper will discuss the state of social medicine in Korea following a review of the literature on the origins and evolution of social medicine. In doing so, this study is aimed at the objectives as follows: 1) To improve the understanding of the medical profession about social medicine in Korea by providing the description of its origins and development; 2 ) To assess the current state of social medicine in Korea and suggest agendas for its future development.

\section{THE ORIGINS, CONCEPTS AND INTERNATIONAL DIFFUSION OF SOCIAL MEDICINE}

With the rapid industrialization and urbanization at the turn of the 19th century, European countries faced many of the social problems, including increased low-wage workers, poor working conditions, lack of housing and sanitation facility. Diseases and deteriorating health conditions among industrial workers and in the low-income population were also serious. Under these circumstances, a group of reformist French physicians and hygienists conducted surveys and statistical studies about the relationships between health problems and social conditions [8]. Furthermore, the first 30 years of the $1800 \mathrm{~s}$ mark the development of modern clinical medicine to replace classical medicine. French physicians realized that many tradi- tional therapeutic techniques were ineffective and, as an alternative, directed attention to hygiene and the influence of social factors on health and disease [9]. Presumably, in addition to such health problems and state of medicine, the zeitgeist in the time of social revolution had made reformist physicians conceive of social medicine.

The term 'social medicine' was first used in 1848, when French Revolution took place in February. In March of the same year, when revolutionary hopes were still running high, Dr. Jules Guérin used the term writing in Gazette Médicale de Paris. In that writing, he appealed to the French medical profession to act for the public good and to help create new society expected from the revolution $[10,11]$. Guérin argued that the goal could be effectively achieved if knowledge and information regarding the relationships among medical issues, social factors and public affairs were systematically integrated into the framework of social medicine.

In Germany, a group of medical doctors and others led by Salomon Neumann, Rudolf Virchow and Rudolf Leubuscher promoted health care reform after the revolution in March 1848 [12]. They fully understood the effect of social factors on health problems. Virchow was a pathologist who provided empirical data supporting the argument that social conditions are important factors in the outbreak of an epidemic. His report, produced in 1848, on the typhus epidemic in the Upper Silesia region of Prussia is considered as a classic in the history of social medicine $[13,14]$.

People are simultaneously biological and social organisms, and thus human health and disease are affected by social factors as well as by biological factors. Included in the basic idea and concept of social medicine is that the interdisciplinary program between medicine and social science would provide medicine with knowledge and skills needed to analyze the social causes of health and illness in the same way as the alliance between medicine and laboratory sciences had provided new insights into the biological, chemical and physical bases of disease [7].

Rudolf Virchow and his colleagues proposed three basic principles regarding the academic and practical aspects of social medicine that were summarized by Rosen [12] as follows: 1 ) the health of the population is a matter of direct social concern; 2) social and economic conditions have an important effect on health, disease and the practice of medicine, and these relations must be subjected to scientific investigation; and 3) steps must be taken to promote health and to combat disease, and the measures involved in such action must be social as well as 
medical. These principles are retained until now, without fundamental changes, even while being adapted to different societies and conditions over an extended period of time [15].

Although social medicine was initiated in France and Germany around the same period, its theory was more actively developed in Germany. The literature on social medicine appeared during the period from 1900 to 1920 in Germany is extensive [12]. Probably, for this reason, Rudolf Virchow is commonly considered as the founder of social medicine [14]. The theory of social medicine developed in Germany had a wide influence on the development of this field in many other European countries [12]. Many medical schools in these countries have retained a commitment to its foundational ideas from the early stage to the present day. For example, a study of the curricula of 32 medical schools in 18 European countries conducted in 2002 revealed that over half of the schools were offering social medicine courses [1].

Social medicine was introduced to Latin America and the US in the 20th century. Social medicine in Latin America was at its prime in the 1930s when Salvador Allende, who later became the president of Chile, was central in promoting the field [16]. In the US, interest grew in social medicine, and discussion of the topic was popular during the period after the end of World War II [8]. For instance, the New York Academy of Medicine hosted an academic conference on social medicine in the spring of 1947 and published the report of the proceedings [17]. In November of the same year, the Milbank Memorial Fund held a roundtable discussion on social medicine [18]. Thereafter, the American medical community avoided using the term social medicine for a substantial period of time. The reason for the avoidance was that the phrase 'social medicine' sounded very much like 'socialized medicine' and the concept incorporated the politically suspect idea of national health system. By the early 1950s, the American social medicine movement lost its momentum during the red scare of what is known as the era of McCarthyism [19,20].

It seems that the term social medicine was no longer considered taboo in mid-1960s. In a survey of American scholars in the fields of preventive medicine, community medicine and public health, conducted during the period from August 1965 to March 1966, it was found that the majority of respondents preferred social medicine as the name of their field of study [20]. Papers on social medicine continued to be published, although not many, discussions on social medicine education began, and practical changes took place as well [21-23]. Re- cently, on April 30, 2016, the Social Medicine Consortium composed of individuals, universities and organizations striving for equity in health held a symposium on social medicine at the University of Minnesota, exemplifying the current perception of and interest in social medicine in the US [24].

\section{INSTITUTIONALIZATION OF SOCIAL MEDICINE AS AN ACADEMIC DISCIPLINE}

Most of established academic disciplines have some common institutional arrangements, such as courses on the disciplinary subject offered by an autonomous organizational unit at colleges or universities and an academic society for the discipline. From early in the 20th century, social medicine began to become institutionalized as an academic discipline, and the institutionalization had been expedited around the end of World War II [12,25,26].

The University of Vienna began to offer a social medicine course in 1909, and the University of Zagreb in Croatia appointed a faculty member of social medicine in 1931. In the UK, the appointment of the first chair of social medicine by Oxford University in 1943 provided a great stimulus to social medicine as an academic discipline. Some two years later, the University of Edinburgh, the University of Birmingham and Trinity College Dublin appointed a faculty member of social medicine $[8,25]$. The Interim Report of The Royal College of Physicians of London, 1943, recommended that every medical school should establish a Department of Social and Preventive Medicine and made recommendations on how the subject should be taught [25]. In 1956, the Society for Social Medicine was established $[25,26]$.

According to Rosen [8], at least until the early 1970s, the content of courses offered by a Department of Preventive Medicine in American medical schools were essentially the same as that offered by a Department of Social Medicine in British medical schools. The history of the Department of Social Medicine at the medical school of the University of North Carolina at Chapel Hill exemplifies the traditional relationship between social medicine and preventive medicine. The Department, originated from the Department of Preventive Medicine in 1952, has kept its current name since 1980 after going through a few instances of reorganization and renaming. Furthermore, the department is responsible for the resident training program for preventive medicine now [27].

The majority of the medical schools in India have the De- 
partment of Preventive and Social Medicine upon the recommendation made at a medical education conference in 1955 [28]. In addition, as mentioned earlier, many medical schools across the world, including those in New Zealand, Malaysia, Thailand and Myanmar, have the Department of Preventive and Social Medicine.

\section{DEVELOPMENT OF MEDICINE AND SOCIAL MEDICINE}

The main medical interventions in modern health care are based on biomedical sciences and technologies that have been developed with advances in human biology, other natural sciences and engineering. New effective biomedical interventions are continuously developed, so that increasingly more diseases can be prevented and treated. However, the fundamental limitations of biomedical interventions should not be overlooked.

As described before, health and disease are affected by social factors as well as by biological factors. For example, people may suffer from preventable communicable diseases due to unsanitary living conditions of slum area and people may die from curable diseases because of delay in seeking adequate medical services due to financial burden. Although the direct cause of their suffering and death was disease, the underlying cause was poverty which is not a biomedical problem. Generally speaking, the social causes of, experiences of and response to diseases and other health problems do not belong to the domain of biomedical science or intervention. Furthermore, many problems in health care associated with the increasing effectiveness and value of medical services, changes in the pattern of illnesses, aging of population and continuous increase in health expenditure are more social than medical.

Advancements in medicine and the development of modern health care changed major causes of morbidity and mortality from infectious to chronic and degenerative diseases. In response to such changes in patterns of disease, health policy focused on changing health behavior and promoting healthy lifestyle. From the 1960s, social medicine also increasingly concentrated on relations between health, illness and social behavior [29]. But empirical studies revealed the limitation of a model of prevention that primarily focused on changing individual behavior [7], and therefore policy and research interest was shifted to addressing the social structural determinants of health and disease. Recently, policy efforts give added emphasis on developing approaches directed to social determinants of health as concern with health inequalities is increased [30-35].

Social medicine explicitly investigates social determinants of health and disease, rather than treating such determinants as mere background to biomedical phenomena [36]. In line with this perspective of social medicine, Link and Phelan [37] argued that epidemiological studies should pay greater attention to basic social conditions questioning the emphasis on such individually-based risk factors as diet, cholesterol level, exercise and the like. They indicated two reasons for this claim. One of their argument is that individually-based factors must be contextualized to craft effective interventions to improve population health. The other is that social factors such as socioeconomic status and social support are likely fundamental causes of disease.

Eisenberg [38] more specifically argued that the distribution of health and disease in human populations reflects where people live, what they eat, the work they do, the air and the water they consume, their activity, their interconnectedness with others and the status they occupy in the social order. Holtz et al. [39] also indicated that each of the risk of exposure, host susceptibility, course of disease and disease outcome is shaped by the social matrix, whether the disease is labeled infectious, genetic, metabolic, malignant, or degenerative. Both of the papers provided illustrations of the social roots of diseases.

Although infectious diseases are clearly caused by biological factors, the patterns and duration of the infection vary according to the characteristics of population, such as size, structure, density, their utilization of health care services and living conditions [38]. By definition, an infectious agent is a necessary cause of the disease. Eliminating the agent eliminates the disease. But it is not a sufficient cause, for not every person exposed to the agent develops clinical disease. The resistance of the host is as decisive as the virulence of the agent. Moreover, the epidemiology of infectious diseases is affected by human organizations as well as by the characteristics of the infectious agent. For example, the penetration of an infectious agent, which is virulent and infectious only in acute phase, into a small community would rapidly kill or immunize so high a proportion of the population that the agent is no longer able to propagate itself. On the other hand, in big cities, such agents have a large enough reservoir to maintain the chain of transmission. And social stratification is to be made in large communities, and disease epidemiology begins to correspond to the stratification. 
The change in the prevalence of type 2 diabetes (NIDDM) among the people of Nauru, a small island in the South Pacific, is a good example of the relationship between socioeconomic factors and diabetes [38]. Until World War II, the main job of Nauruans was fishing and farming for subsistence which required high energy expenditure. After the war, introduction of phosphate mining by foreign companies yielded rental income for Nauruans that rapidly transformed them into wealthy and sedentary people. Virtually all foodstuffs were imported, and most had a high calorie content; obesity became ubiquitous. NIDDM, previously minimal, began to reach epidemic proportions in the 1950s, and in the late 1990s, afflicted almost two-thirds of 55-year-old to 64-year-old adults. The distribution of the disease among Nauruans has continued to change during the past 50 years. Health surveys revealed that the age standardized prevalence of impaired glucose tolerance rose to $21 \%$ in the mid-1970s and then declined to half that value by the late 1980s; yet, the risk factors persisted. According to Eisenberg [38], the plausible explanation for the rise and subsequent fall is that NIDDM resulting from the affluent lifestyle has already afflicted most of the genetically susceptible Nauruans, leaving a residual population of relatively resistant individuals.

Neel [40] has proposed the "thrifty genotype" hypothesis to explain the epidemiological changes in diabetes, like those observed in Nauru. In a situation where there is a fluctuating food supply and frequent famines, greater fat stores would be helpful for surviving subsequent periods of starvation. Individuals with thrifty adaptations (i.e., those able to release insulin rapidly when a temporary food glut becomes available) can convert most of their ingested calories into fat. The very same genotype becomes a handicap in the presence of abundant highcalorie foodstuffs and reduced physical activity. This hypothesis indicates that social conditions, through interaction with genotype, can influence the distribution of diseases in a population.

The prevalence of heart disease and diabetes is two to three times higher in African Americans than in whites, but representative surveys of Caribbean populations of African origin have revealed prevalence rates two to five times lower than those of blacks in America or Britain. This suggests that racial disparities in health status observed in the US are associated with social contexts rather than with biological attributes including genotype [41].

The Center for Interdisciplinary Health Disparities Research at the University of Chicago (CIHDR) proposed a downward causal model or a multilevel causal model of the mechanism through which social factors cause diseases and influence health outcomes [33]. According to the model, upstream determinants at the social and environmental levels influence and regulate events at lower levels, that is, from individual behavior and physiology to the cellular and genetic interactions with health and disease. And feedback also occurs from lower to higher levels, with genetic and biological factors, influencing phenomena above them. In the US, despite the fact that white women are more likely to develop breast cancer, black women are more likely to die from it. Through the study of this disparity, CIHDR illustrated the applicability of the model for understanding the causal role of certain social factors in developing diseases.

Several empirical studies on the effects of social factors on health and disease were briefly reviewed. These studies indicate the inherent social basis of disease causation that is part of the basic concept and theory of social medicine. And they provide some rationale for Einsenberg's claim that all medicine is inescapably social [38].

\section{SOCIAL MEDICINE IN KOREA}

Since Japanese medicine was influenced by German medicine, it is probable that social medicine was known in Korea during the period of Japanese rule. Hong-Jong Yoo, a Korean physician, used the term social medicine in an essay titled "Two major harms from the viewpoint of hygiene," printed in the first issue of Gaebyuk published in 1920 [42], and the term appeared in newspapers around the time. But the extent to which social medicine was established as an academic discipline or as a specialty of medicine in Korea is not known.

The term social medicine has been rarely used in Korea after the liberation from Japanese rule either. Exchange with American medicine, which became active from around the 1950s, was the driving force for the development of Korean medicine. But social medicine was not introduced, presumably because American medicine avoided using the term for a substantial period of time, especially for some years from the era of McCarthyism in early 1950 s. However, some research papers, which considered social factors as part of study variables, used the term social medicine in the title like'socio-medical study.' (There are papers titled "Social medicine" [43] and "A study on the development of social medicine curriculum" [44], but their content is not about social medicine but about medical education.) 
The establishment of Institute of Social Medicine, Hallym University (The Institute is now named Health Services Research (enter.) in 1984 was the first formal use of the term in Korea. In 1985, Hallym University College of Medicine established the Department of Social Medicine (literal translation of Korean name) instead of the Department of Preventive Medicine which is the common name used in Korean medical colleges. A few years later, two more newly founded colleges of medicine established the Department of Social Medicine. Their English name is the Department of Social and Preventive Medicine. As the reasons for using social medicine instead of or in combination with preventive medicine in those medical colleges, two points are indicated. First, fundamental knowledge and technologies for prevention are developed by all the medical specialties and most of preventive services for individuals are performed at the departments of clinical medicine, so that prevention cannot be monopolized by a certain specialty. In fact, prevention is the concern of all the medical specialties including basic medical sciences [45]. Second, preventive medicine, as the title of specialty, does not reflect the fact that Korean preventive medicine deals with much broader content than prevention. At this point, we may ask a couple of questions. What is the relationship between social medicine and preventive medicine? Can the use of the term 'social medicine' help resolve the problems faced with the use of the term 'preventive medicine'?

In the textbook edited and published by the Korean Society for Preventive Medicine [46], preventive medicine is defined as one of medical specialties aimed to protect, maintain and promote health and well-being of individuals and groups of people, and to prevent disease, disability, and premature death. This definition implies that preventive medicine is distinguished from other medical specialties by its two characteristics, focus on prevention and concern with groups of people as well as individuals. Understanding of patterns of health and illness in groups of people and making interventions at the population level to improve their health require consideration of the effects of various social factors on health and health care delivery system. Therefore, the biomedical model of health and disease is not appropriate for dealing with many of the problems and issues involved in the research and practice of preventive medicine $[47,48]$. These concepts of preventive medicine associated with its population perspective to health and disease are the very basic ideas and concepts of social medicine and the term 'social medicine' apparently reflects such concepts better than the term 'preventive medicine'. In fact, once the two terms were often used interchangeably in America [49], perhaps on the basis of such commonality. In the light of the conceptual commonality, it is understandable that Korean preventive medicine deals with many of the subject matters of social medicine.

A quick observation of the subjects of the aforementioned textbook published by the Korean Society for Preventive Medicine is made to confirm that they include those of social medicine. The subjects of the book are grouped into four parts: 'Health and Disease' (part I); 'Epidemiology and Its Applications' (part II); 'Environment and Health' (part III); and 'Health Care Services and Management' (part IV). In describing the concepts related to preventive medicine and public health in part I, socioeconomic, cultural and political factors are considered as part of the determinants of health. This perspective to health is in agreement with the concepts of social medicine. Epidemiology, discussed in part II, is used as a methodology in social medicine as well. Besides, epidemiology of most of diseases are affected by social factors as well as by biological factors. The subjects of part III, environmental pollution, environmental contamination and occupational diseases are also closely associated with social and economic conditions. Health care delivery system, health insurance and health behavior included as the subjects of part IV are also important issues for social medicine. Even through a quick fragmentary observation, it is found that Korean preventive medicine incorporates a great deal of social medicine contents.

In Korea, the term social medicine is rarely used but many of its subject matters are incorporated into preventive medicine as reflected in a text book. But the implicit incorporation of fragmentary contents of social medicine without any discussion of its concepts and theory may be of little help for understanding even the basics of social medicine, such as the need for and the significance of investigating the effects of social conditions on health, disease and health care. Therefore, efforts should be made to supplement social medicine contents of preventive medicine through formalizing linkages between the two fields. One way of doing so is to change the title of 'preventive medicine' course in medical colleges to 'preventive and social medicine,' as in many other countries and adjust the contents of teaching and textbook. It is believed that this change will be also helpful for clearly defining the academic and practical identity of preventive medicine. 


\section{SUMMARY AND CONCLUSION}

It was observed that social medicine is recognized as a specialty of medicine in many countries. The Korean medical community, however, does not seem to be aware of that social medicine is one of medical specialties, but it does not mean that nothing about social medicine is dealt with in medical colleges or none of social medicine approaches is employed in health care services. Since social medicine has evolved in diverse ways in different countries, the main concerns and subject matters of teaching and research may differ to some extent among countries. Based upon these observations, this paper is intended: 1) to improve medical profession's understanding of social medicine in Korea through providing the description of its origins and development; and 2) to assess the current state of social medicine in Korea and suggest agendas for its future development.

Included in the core principles of social medicine are: 1) that social and economic conditions have an important effect on health, disease and the practice of medicine, and these relations must be subjected to scientific investigation; and 2) that the measures to promote health and combat disease must be social as well as medical. Interests in the relationships between health and social factors began in the 18th century, but the term 'social medicine' was first used in 1848 by a French doctor, Jules Guérin in the year of the February Revolution in France. In the same year, Rudolf Virchow and his colleagues initiated social medicine in Germany.

Social medicine initiated in France and Germany had a wide influence on the development of this field in many other European countries. Interest in social medicine grew and discussion of the topic was popular in the US for some time after World War II. However, the American medical profession avoided using the term for a substantial period of time. The reason for the avoidance was that the phrase 'social medicine' sounded very much like 'socialized medicine' and the concept incorporated the politically suspect idea of national health system. By the early 1950s, the American social medicine movement lost its momentum during the red scare of what is known as the era of McCarthyism. Presumably because of the avoidance of the term by American medicine, which has widely influenced Korean medicine, social medicine has not been introduced to Korea.

Korean preventive medicine is distinguished from other medical specialties by its two characteristics, focus on prevention and concern with groups of people as well as individuals. Understanding of patterns of health and illness in groups of people and making interventions at the population level to improve their health require consideration of the effects of various social factors on health, disease, and health care delivery system. In other words, Korean preventive medicine deals with, besides prevention, health problems at the population level that are inescapably social. These concepts of preventive medicine associated with its population perspective to health and disease are the very basic ideas and concepts of social medicine.

In Korea, the term social medicine is rarely used but many of its subject matters are included in preventive medicine as reflected in a textbook. But it is not likely that further systematic development of social medicine would be made because there has never been any academic discussion of the concepts and theory of social medicine, upon which such development can be based. Indication is that efforts should be made to supplement social medicine contents of preventive medicine through formalizing the linkages between preventive medicine and social medicine. One way of doing so is to change the title of 'preventive medicine' course in medical colleges to 'preventive and social medicine' like in many other countries, and adjust the course contents in accordance with the new title.

\section{CONFLICT OF INTEREST}

The authors have no conflicts of interest associated with the material presented in this paper.

\section{SUPPLEMENTAL MATERIAL}

Supplemental material (Korean version) is available at http: //www.jpmph.org/.

\section{ORCID}

Dal Sun Han http://orcid.org/0000-0002-3429-1665

Dong-Hyun Kim http://orcid.org/0000-0003-3352-5375

Yong-jun Choi http://orcid.org/0000-0002-1622-3175

\section{REFERENCES}

1. Dusek T, Bates T. Analysis of European medical schools' teaching programs. Croat Med J 2003;44(1):26-31.

2. Henderson GE, King NM, Strauss RP, Estroff SE, Churchill LR, 
editors. The social medicine reader. Durham: Duke University Press; 1997.

3. King NM, Churchill LR, Estroff SE, Henderson GE, Oberlander J, editors. The social medicine reader, 2nd ed., vol. 1: patients, doctors, and illness. Durham: Duke University Press; 2005.

4. Henderson GE, Estroff SE, Churchill LR, King NM, Oberlander J, Strauss RP, editors. The social medicine reader, 2nd ed., vol. 2: social and cultural contributions to health, difference, and inequality. Durham: Duke University Press; 2005.

5. Oberlander J, Churchill LR, Estroff SE, Henderson GE, King NM, Strauss RP, editors. The social medicine reader, 2nd ed., vol. 3: health policy, markets, and medicine. Durham: Duke University Press; 2005.

6. Lee JC. The development of German social medicine in the nineteenth century. Uisahak 1994;3(1):20-29 (Korean).

7. Porter D. How did social medicine evolve, and where is it heading? PLoS Med 2006;3(10):e399.

8. Rosen G. The evolution of social medicine. In: Freeman HE, Levine S, Reeder LG, editors. Handbook of medical sociology. 2nd ed. Englewood Cliffs: Prentice-Hall; 1972, p. 30-60.

9. Starr P. The social transformation of American medicine: the rise of a sovereign profession and the making of a vast industry. New York: Basic Books; 1982, p. 55.

10. Cockerham WC, Ritchey FJ. Dictionary of medical sociology. Westport: Greenwood Press; 1997, p. 119-120.

11. Hobson W. What is social medicine? Br Med J 1949;2(4619): 125-130.

12. Rosen $\mathrm{G}$. What is social medicine? a genetic analysis of the concept. Bull Hist Med 1947;21(5):674-733.

13. Taylor R, Rieger A. Rudolf Virchow on the typhus epidemic in Upper Silesia: an introduction and translation. Sociol Health IIIn 1984;6(2):201-217.

14. Waitzkin H. One and a half centuries of forgetting and rediscovering: Virchow's lasting contributions to social medicine. Soc Med 2006;1(1):5-10.

15. Anderson MR, Smith L, Sidel VW. What is social medicine? Mon Rev 2005;56(8):27-34.

16. Waitzkin H, Iriart C, Estrada A, Lamadrid S. Social medicine then and now: lessons from Latin America. Am J Public Health 2001;91(10):1592-1601.

17. Galdston I, editor. Social medicine: its derivations and objectives; the New York Academy of medicine institute on social medicine, 1947. New York: Commonwealth Fund; 1949.

18. Rosen G. Approaches to a concept of social medicine; a historical survey. Milbank Mem Fund Q 1948;26(1):7-21.
19. Morman ET. George Rosen, public health, and history. In: Rosen G, editor. A history of public health. Expanded ed. Baltimore: Johns Hopkins University Press; 1993, p. Ixix-Ixxxviii.

20. Susser M. Teaching social medicine in the United States. Milbank Mem Fund Q 1966;44(4):389-413.

21. Madison DL. Introduction: where medicine and society meet. In: Social medicine, 20th anniversary report of the Department of Social Medicine, School of Medicine, University of North Carolina. Chapel Hill: University of North Carolina; 1998; p. 7-18.

22. Westerhaus M, Finnegan A, Haidar M, Kleinman A, Mukherjee J, Farmer P. The necessity of social medicine in medical education. Acad Med 2015;90(5):565-568.

23. Kasper J, Greene JA, Farmer PE, Jones DS. All health is global health, all medicine is social medicine: integrating the social sciences into the preclinical curriculum. Acad Med 2016;91(5): 628-632

24. Social Medicine Consortium. Conference 2016: reimagining social medicine [cited 2016 May 1]. Available from: http:// www.socialmedicineconsortium.org/conferencedetails/.

25. Pemberton J. Origins and early history of the Society for Social Medicine in the UK and Ireland. J Epidemiol Community Health 2002;56(5):342-346.

26. Society for Social Medicine. Constitution of the society; 2015 [cited 2016 May 1]. Available from: https://socsocmed.org.uk/ about/constitution/.

27. UNC School of Medicine. UNC social medicine [cited 2016 May 1]. Available from: http://www.med.unc.edu/socialmed.

28. Thakur HP, Pandit DD, Subramanian P. History of preventive and social medicine in India. J Postgrad Med 2001;47(4):283285.

29. Porter D. Transformations in social medicine. Lancet 1999;354 Suppl:SIV57.

30. Marmot M. Social determinants of health inequalities. Lancet 2005;365(9464):1099-1104.

31. Farmer PE, Nizeye B, Stulac S, Keshavjee S. Structural violence and clinical medicine. PLoS Med 2006;3(10):e449.

32. Syme SL. Reducing racial and social-class inequalities in health: the need for a new approach. Health Aff (Millwood) 2008:27(2):456-459.

33. Gehlert S, Sohmer D, Sacks T, Mininger C, McClintock M, Olopade $\mathrm{O}$. Targeting health disparities: a model linking upstream determinants to downstream interventions. Health Aff (Millwood) 2008;27(2):339-349.

34. Braveman P, Egerter S, Williams DR. The social determinants of 
health: coming of age. Annu Rev Public Health 2011;32:381398.

35. World Health Organization. Health topics: social determinants of health [cited 2016 Apr 26]. Available from: http://who.int/ topics/social_determinants/en/.

36. Krieger N. A glossary for social epidemiology. J Epidemiol Community Health 2001;55(10):693-700.

37. Link BG, Phelan J. Social conditions as fundamental causes of disease. J Health Soc Behav 1995;Spec No:80-94.

38. Eisenberg L. Does social medicine still matter in an era of molecular medicine? J Urban Health 1999;76(2):164-175.

39. Holtz TH, Holmes SM, Stonington S, Eisenberg L. Health is still social: contemporary examples in the age of the genome. PLoS Med 2006;3(10):e419.

40. Neel JV. Diabetes mellitus: a "thrifty" genotype rendered detrimental by "progress"? Am J Hum Genet 1962;14:353-362.

41. Cruickshank JK, Mbanya JC, Wilks R, Balkau B, McFarlane-Anderson N, Forrester T. Sick genes, sick individuals or sick populations with chronic disease? The emergence of diabetes and high blood pressure in African-origin populations. Int J Epide- miol 2001;30(1):111-117.

42. Yoo HJ. Two major harms from the viewpoint of hygiene. Gaebyuk 1920;1:108-111 (Korean).

43. Jeon WT. Social medicine. Yonsei J Med Educ 2001;3(2):1-13 (Korean).

44. Chun WT, Kim S, Yang EB. A study on the development of social medicine curriculum. Korean J Med Educ 2001;13(2):201212 (Korean).

45. Stevens R. American medicine and the public interest. New Haven: Yale University Press; 1971, p. 330.

46. Korean Society for Preventive Medicine. Preventive medicine and public health. Rev. ed. Seoul: Gyechuk Munwhasa; 2011, p. 19 (Korean).

47. Rose G. Sick individuals and sick populations. Int J Epidemiol 1985;14(1):32-38.

48. Rose G. The strategy of preventive medicine. Oxford: Oxford University Press; 1992.

49. The distinction between public health and community/social/ preventive medicine. J Public Health Policy 1985;6(4):435-439. 


\title{
Origins and Evolution of Social Medicine and Contemporary Social Medicine in Korea
}

\author{
Dal Sun Han', Sang-Soo Bae ${ }^{1,2}$, Dong-Hyun Kim ${ }^{1,3}$, Yong-jun Choi ${ }^{1,2}$ \\ ${ }^{1}$ Department of Social and Preventive Medicine, Hallym University College of Medicine, Chucheon; ${ }^{2}$ Health Services Research Center, Hallym \\ University, Chucheon; ${ }^{3}$ Research Institute of Clinical Epidemiology, Hallym University, Chucheon, Korea
}

\section{사회의학의 기원, 진화 및 한국 사회의학의 실상}

\author{
한달선 ${ }^{1}$, 배상수 ${ }^{1,2}$, 김동현 ${ }^{1,3}$, 최용준 ${ }^{1,2}$
}

1한림대학교 의과대학 사회의학교실, ${ }^{2}$ 한림대학교 사회의학연구소, ${ }^{3}$ 한림대학교 임상역학연구소

유럽의 많은 의과대학들은 사회의학을 교과목으로 개설하고 있으며, 미국에서는 일부 의과대학들이 사회의학을 department의 명칭에 사용하고 있다. 그러나 한국에서는 사회의학의 도입이 제대로 진행되지 못했다. 이는 한국 의학에 지대한 영 향을 미친 미국 의학계가 한동안 그 용어와 원리를 수용하지 않았었기 때문일 것이다. 이러한 상황 인식을 바탕으로 1) 사회 의학의 기원과 진화에 관하여 기술하고, 이어서 2) 한국 사회의학의 실상에 대하여 간략히 논의할 것이다. 사회의학은 1848 년 프랑스와 독일에서 창시되어, 국제적으로 다양한 발전 과정을 거쳤다. 사회적, 경제적 여건이 건강, 질병 및 의료서비스 에 미치는 영향이 심대하며, 따라서 그에 대한 과학적 연구가 필요하다는 것이 사회의학의 핵심적 개념에 속한다. 한국에서 는 사회의학이 거의 사용되지 않는 용어지만, 그 내용은 의과대학 예방의학 교과과정에 도입된 상태이다. 그러나 이러한 내 용적 수용은 사회의학에 대한 논의와 이해에 근거해서 이루어진 것이 아니므로 그 의의와 가치의 전달에 한계가 있다. 따라 서 예방의학과 사회의학의 연계관계를 분명히 밝히고, 체계화하는 노력이 필요하다. 구체적으로는 의과대학 예방의학 과 목의 명칭을 많은 나라에서처럼 예방사회의학으로 변경하고, 명칭에 부합하도록 내용을 조정.보완하는 방안을 검토할 필 요가 있다.

핵심어: 사회의학, 예방의학, 역사, 한국

서론

유럽의 많은 의과대학들은 사회의학(social medicine)을 교과목으로 개설하고 있으며[1], 미국의 일부 의과대학들 은 department의 명칭에 사회의학을 사용하고 있다. Harvard University Medical School의 Department of Global Health and Social Medicine, Albert Einstein College of Medicine의 Department of Family and Social Medicine, University of North Carolina at Chapel Hill Medical School의 Department of Social Medicine 등이 그러한 예이다. 뉴질랜드, 말레이시아, 태국, 미얀마, 인도 등에는 Department of Preventive and Social Medicine을 갖고 있는 의과대학들이 많다. 그리고 미국 Uni- versity of North Carolina at Chapel Hill 의과대학의 Department of Social Medicine 교수진이 편집한 The Social Medicine Reader 초판이 1997년에 발간됐고[2], 2005년에는 3권으로 증보된 제2판이 발간됐다[3-5]. 이러한 사실들은 사회의학 이 많은 나라 의학계가 인정하는 전문분야임을 적시한다.

한국에서는 의학계가 사회의학이라는 분야의 존재를 인 지하고 있는지 의문스러울 만큼 사회의학은 의사들에게도 낯선 용어이다. 사회의학에 관한 논의가 없었을 뿐만 아니 라, 19 세기 독일 사회의학의 역사적 발전을 개관한 논문[6] 한 편을 제외하면 소개한 글도 찾아보기 어렵다. 이와 같은 상황인식에서 출발하여 한국 의학계의 사회의학에 대한 이해를 돕기 위해서 문헌고찰을 통하여 사회의학의 기원 


\section{Journal of}

과 진화에 대하여 기술할 것이다.

사회의학이란 용어가 거의 사용되지 않는다는 사실이 한국 의학이 사회의학적 내용을 전혀 다루지 않는다거나 보건의료에서 사회의학적 접근이 사용되지 않는다는 것을 의미하지는 않는다. 사회의학은 국제적으로 다양하게 진 화해 왔으며, 따라서 구체적 내용은 국가 또는 연구자들 사 이에 다소간 차이가 있다[7]. 이러한 관점에서 한국 사회의 학의 실상을 논의할 것이다.

요약하면 이 논문의 목적은 다음의 두 가지이다.

1) 사회의학의 기원과 진화에 대하여 기술함으로써 한국 의학계의 사회의학에 대한 이해를 돕는다.

2) 한국 사회의학의 실상을 정리하고 발전을 위한 의제를 제시한다.

\section{사회의학의 발상, 기본 개념 및 국제적 확산}

19세기 전후 프랑스와 유럽 여러 나라들에서는 혁신적 산업화와 급속한 도시화로 인하여 저임금 노동자들의 증 가, 열악한 노동조건, 주택 부족, 위생시설 불비 등의 다양 한 문제들이 발생하였으며, 산업노동자, 빈곤계층 등의 건 강상태 악화와 질병문제도 심각하였다. 이러한 상황에서 프랑스의 일부 활동적 의사들과 위생학자들이 도시지역 노동자들과 그들의 근로환경에 대한 조사연구를 실시하여 건강문제가 사회적 요인들과 상관이 있다는 사실을 밝히 기 시작했다[8]. 그리고 1800 년대 초기 약 30 년은 고전적 의 학에서 현대적 임상의학으로 발전하는 변화가 시작된 시 기로서, 프랑스 의사들은 종래의 많은 치료기법들이 효과 가 없음을 알게 됐고, 대안으로 예방적 위생과 사회적 요인 이 건강과 질병에 미치는 영향에 주목하였다[9]. 이와 같은 건강문제 및 의학 관련 상황과 더불어 사회적 변혁기의 이 념적 사조와 시대정신이 개혁적 의사들이 사회의학을 구 상하는 바탕이 됐을 것이다.

사회의학이라는 용어가 처음 쓰인 것은 프랑스에서 2월 혁명이 있었던 1848 년이었다. 혁명이 제시한 비전에 대한 기대가 아직 고조돼 있었던 같은 해 3월, 의사 Jules Guérin은 자신이 편집자로 있던 Gazette Médicale de Paris에 게재한 글 에서 의료계가 공익을 위하여 일함으로써 혁명에 의해서 길이 열린 새로운 사회를 구현하는 데 기여하자고 호소하 면서, 사회의학이란 용어를 사용하였다[10,11]. 그는 의학 적 문제가 사회적 요인이나 공적 사업과 어떤 관계가 있는 지에 대한 지식과 자료를 사회의학의 틀로 종합해서 체계 화하면 소기의 성과를 효과적으로 거둘 수 있을 것이라고 주장하였다.

독일에서도 1848 년 3월의 혁명으로 조성된 변혁기에 $\mathrm{Sa}-$ lomon Neumann, Rudolf Virchow, Rudolf Leubuscher 등이 보
건의료 개혁을 추진하였다[12]. 독일의 이들 개혁 추진세력 은 건강문제에 대한 사회적 요인들의 작용을 충분히 인식 하고 있었다. Virchow는 세포병리학자로서 발진티푸스 및 콜레라 유행, 결핵의 집단 발생 등에 대한 조사연구를 통하 여 사회적 여건이 감염병 유행에 있어서 중요한 요인으로 작용한다는 실증적 논거가 되는 자료들을 제시하였다. 특 히 1848년에 발표된 프러시아의 Upper Silesia 지역에서 발 생한 발진티푸스 유행에 대한 조사보고서는 사회의학 초 기 발전의 계기가 된 역사적 업적으로 평가된다[13,14].

인간은 생물체임과 동시에 사회적 존재이므로 인간의 건강과 질병은 본질적으로 생물현상이면서 또한 사회현상 이라는 양면성을 갖고 있는 것이다. 생물체로서의 인간의 건강문제에 대한 지식과 기술이 자연과학을 토대로 발전 해 왔듯이, 사회과학과의 학제간 접근을 통하여 사회적 존 재로서의 인간의 건강과 질병에 대한 지식의 향상과 체계 화를 이룰 수 있으리라는 기대가 사회의학의 기본 발상과 개념의 중요한 부분이다[7].

Rudolf Virchow 등의 독일 보건의료 개혁가들은 사회의학 의 학문적, 실천적 측면에 대하여 기본원칙으로 세 가지를 제시하였다[12]. (1) 건강은 사회적 차원에서 관심을 가져 야 하는 과제이며, 사회는 구성원들의 건강을 보호하고 보 장할 의무가 있다. (2) 사회적, 경제적 여건이 건강과 질병, 의료서비스에 미치는 영향이 심대하므로 그에 대한 과학 적 연구가 필요하다. (3) 사회는 건강증진과 질병관리를 위 한 조치를 취해야 하며, 의학적 수단과 더불어 사회적 수단 도 동원해야 한다. 이 원칙들은 오랜 기간 상이한 사회와 여 건에 적용되는 과정에서도 근원적 변화 없이 오늘날까지 유지되고 있다[15].

사회의학의 발상은 프랑스와 독일에서 거의 같은 시기 에 시작됐으나, 이론적 작업은 독일에서 더 활발하여 1900 년부터 1920년 사이에 사회의학에 관하여 많은 저서들이 출간되었다[12]. 오늘날 Rudolf Virchow가 흔히 사회의학의 창시자로 일컬어지는 것은 이러한 사실 때문일 것이다[14]. 독일에서 개발된 사회의학 이론은 유럽의 여러 나라들로 확산되며 발전하였다[12]. 오늘날까지 유럽의 많은 대학들 은 사회의학이라는 용어를 사용하면서 초기 발상의 근간 을 계속해서 이어오고 있다. 예컨대 2002년 유럽 18 개국 32 개 의과대학에 대한 조사에서 반수 이상의 대학이 사회의 학이란 명칭의 교과목을 개설하고 있었다[1].

20세기에 들어서는 라틴아메리카와 미국에도 사회의학 이 도입되었다. 라틴아메리카의 사회의학은, 병리학자이 며 훗날 칠레대통령을 역임한 Salvador Allende가 핵심적 역 할을 했던 1930년대에 활기를 띠었던 것으로 평가된다[16]. 미국에서는 제 2 차 세계대전 종전 후 얼마 동안 사회의학에 대한 관심과 논의가 활발하였다[8]. 예컨대 1947년 봄, New 
York Academy of Medicine이 사회의학에 관한 학술모임을 주최하고 보고서를 펴냈으며[17], 같은 해 11월에 Milbank Memorial Fund는 사회의학을 주제로 원탁토론회를 개최하 였다[18]. 그러나 이후 상당 기간 미국 의학계는 social medicine이란 용어를 기피했었다. 미국 의학계가 'social medicine'이라는 용어를 금기시했던 이유는 의사들이 강한 저항 감을 갖고 있던 'socialized medicine (사회주의 의료제도)'과 어감이 비슷하고 국가관리의료체계를 함의한다고 보았기 때문이라고 지적되며, 이러한 기피현상은 1950 년대 초반 에 미국을 휩쓴 공산주의자 색출 열풍인 매카시즘 때문에 더 심했던 것으로 알려져 있다[19,20].

미국의 예방의학, 지역사회의학 또는 공중보건학 분야 의 학계인사들을 대상으로 1965년 8월부터 1966년 3월까지 시행된 조사에서 다수의 응답자들이 자신이 전공하는 학 과목의 명칭으로 사회의학을 선호했다는 보고[20] 등에 비 추어 '사회의학'이 1960년대 중반부터는 더 이상 금기가 아 니었던 것으로 보인다. 사회의학에 관한 논문들이 수가 많 지는 않았지만 계속 발표되었고, 사회의학 교육 관련 논의 도 이루어졌으며, 실질적 변화도 일어났다[21-23]. 건강의 평등을 위해서 노력하는 개인, 대학, 단체 등으로 구성된 사 회의학 컨소시엄이 최근, 즉 2016년 4월 30일에 미국 미네 소타대학교에서 사회의학 심포지엄을 개최했다는 사실도 항간의 정황을 말해주는 실례가 될 것이다[24].

\section{사회의학의 학문적 기반 제도화}

모든 학문 분야에서 고유의 전문성을 인정받고 응분의 위상을 확보하는 데 중요한 제도적 기반은 대학에서의 교 과목 개설, 독자적 조직 구축 및 학회 운영일 것이다. 사회 의학이 제도적 측면에서 의학의 독자적 전문분야의 하나 로 정립되기 시작한 것은 20 세기에 들어서였고, 제 2 차 세계 대전 말경에야본격적으로 진행되었다 $[12,25,26]$.

1909년에 University of Vienna에 사회의학 강좌가 개설됐 으며, 크로아티아의 University of Zagreb는 1931년에 사회의 학 교수를 임용하였다. 영국에서는 1943년에 University of Oxford가 최초로 사회의학 주임교수를 임명함으로써 사회 의학이 학문적으로 정립되는 계기를 마련하였다. 또한 1945년에는 University of Edinburgh, University of Birmingham 및 Trinity College Dublin도 사회의학 교수를 임용하였 다 8 ,25]. 그리고 The Royal College of Physicians of London은 1943년 보고서에서 모든 의과대학이 Department of Social and Preventive Medicine을 설치하도록 건의하였으며 [25], 1956년에는 영국의 사회의학회(Society for Social Medicine) 가설립됐다[25,26].

Rosen [8]에 의하면, 적어도 1970년대 초반까지는 미국의
Department of Preventive Medicine이 개설한 과목의 내용이 영국 의과대학의 사회의학과 본질적으로 차이가 없었다. 미국 University of North Carolina 의과대학의 Department of Social Medicine이 1952년에 Department of Preventive Medicine으로 출발하여 몇 차례의 조직 개편과 개칭을 거쳐서 1980년부터 지금의 명칭으로 운영되고 있으며, 현재 예방 의학 전공의 수련프로그램을 담당하고 있다는 사실은 양 자간의 전통적 관계를 말해주는 사례가 될 것이다[27].

인도에서는 1955년 의학교육 학술대회의 건의에 따라 전 국의 대다수 의과대학들이 Department of Preventive and Social Medicine을 설치하였다[28]. 그리고 앞에서 언급한 바와 같이 Department of Preventive and Social Medicine을 설치한 의과대학들은 인도 이외의 다른 나라들에서도 흔히 볼 수 있다.

\section{의학의 발전과 사회의학}

현대의학과 의료의 주축은 생물학을 비롯한 자연과학적 지식의 바탕 위에서 인간의 건강이나 질병문제를 이해함 으로써 문제의 예방, 진단, 치료 방안을 개발하여 활용하는 생물학적 의학 또는 생의학(生醫學, biomedicine)적 접근이 다. 자연과학과 공학의 발달로 인간의 질병과 건강에 관한 생의학적 지식과 기술이 계속 개발됨으로써 많은 질병문 제를 효과적으로 치료 또는 관리할 수 있게 되었고, 이와 같 은 발전은 앞으로도 계속될 것으로 내다보인다. 그렇지만 생의학적 지식을 토대로 하는 건강문제의 해결에는 근원 적 한계가 있음을 간과해서는 안 되겠다.

전술한 바와 같이 질병을 포함한 건강문제는 생물적 개 체로서의 인간문제인 동시에 사회적 존재로서의 인간문제 라는 두 가지 측면이 있으므로 생의학적으로는 설명도, 해 결도 불가능한 것들이 있는 것이다. 예컨대 가난하고 생활 환경이 비위생적이기 때문에 수인성 감염병에 걸렸다면, 그리고 진료비가 부담스럽거나 교통이 불편해서 의료기관 방문과 수술이 지연되어 충수돌기염 환자가 사망했다면 어떻게 설명해야 할까? 생물학적 의학에서는 이들 질병의 원인, 예방법, 치료방법 등을 완전히 알고 있어 이미 해결되 었고 더 이상 문제가 안 되는데, 왜 이들 질병으로 인한 환 자 또는 사망자가 발생할까? 이유는 간단하다. 감염병 발생 이나 충수돌기염으로 인한 사망은 생의학적 문제지만, 문 제가 발생한 당초의 원인은 가난하여 비위생적 환경에서 사는 것이나, 비용 때문에 적기에 진료를 받지 못한 것인데, 이들 원인은 생의학적 의료로 해결할 수 없기 때문이다. 일 반론적으로 말하면 건강과 질병은 본질적으로 자연현상일 뿐만 아니라 사회현상이기도 하므로 아예 생물학적 의학 의 대상이 아닌 과제들이 있는 것이다. 


\section{Journal of}

의학지식과 의료기술의 발달, 환경위생과 영양상태의 향상 등으로 많은 나라에서 감염성질환이 대폭 감소한 반 면, 대사증후군 등의 만성병이 사망과 이환의 주된 원인이 되었다. 보건정책은 만성질환 문제에 대응하여 건강의 견 지에서 바람직한 생활양식과 행동의 실천을 유도, 확산하 는 데 주력했으며, 이에 따라 사회의학은 1960년대부터 건 강문제와 질병을 개인 행동이나 생활양식과의 관계에 초 점을 맞추어 이해하기 위한 노력에 집중하였다[29]. 그러나 개인의 건강행태 변화와 그 건강효과에 한계가 있음이 경 험적으로 밝혀짐에 따라서 건강문제와 사회의 구조적 속 성 간의 관계에 대한 관심이 증가하는 경향이 나타났다[7]. 특히 근래에는 건강불평등이 중요한 정책 과제가 됨에 따 라서 정책적 접근을 전통적 보건의료 부문이나 개인적 위 험요인들에 한정하지 말고 건강의 사회적 결정요인들을 대상으로 정책수단을 전개해야 한다는 주장이 힘을 얻고 있다[30-35].

사회의학은 사회적 요인들이 인구집단의 건강과 질병문 제의 배경요인으로 영향을 미치는 데 그치는 것이 아니라 직접 작용하는 결정요인의 일부라고 본다[36]. Link와 Phelan이[37] 질병의 근접요인이라 할 수 있는 식생활, 콜레스테 롤, 신체활동 등의 개인적 위험요인들에 관심을 집중하는 연구동향의 타당성에 대하여 의문을 제기하면서 기본적 사회여건들에 더 많은 관심을 가져야 한다고 주장한 것은 건강 결정요인에 대한 사회의학적 견해와 맥을 같이한다 고 이해할 수 있겠다. 그들은 그러한 주장의 이유로 두 가지 를 들고 있다. 하나는 사람들이 건강 위험요인들을 갖게 되 는 정황을 파악할 필요가 있기 때문이고, 다른 하나는 사회 경제적 상태 등의 사회적 요인들이 질병의 결과에 다각적 으로 영향을 미치는 근원적 원인이기 때문이라는 것이다.

Eisenberg [38]는 좀 더 구체적으로 인구집단의 건강과 질 병문제는 사람들이 어디에 사는지, 무엇을 먹는지, 무슨 일 을 하는지, 그들이 호흡하는 공기와 마시는 물은 어떠한지, 사회계층상 어느 지위에 속하는지 등에 따라서 달라진다 고 주장하였다. Holtz 등[39]은 질병의 사회적 근원을 몇 가 지 예시하면서 Eisenberg가 주장한 건강과 질병에 대한 사 회적 요인들의 작용을 재확인하였다. 이처럼 사회적 요인 들이 건강과 질병에 중요하게 작용한다는 일반론을 뒷받 침하는 실증적 자료들을 몇 가지 살피기로 한다.

감염병의 원인은 생물학적 요인임이 분명하지만, 인구 집단의 규모, 구조, 밀집상태, 보건의료서비스 이용, 생활환 경 등에 따라서 감염 양상이나 지속기간이 달라진다[38]. 병원체는 감염병 발생의 필요조건이다. 다시 말해서 병원 체를 제거하면 감염병도 없어진다. 그러나 병원체에 감염 된 사람들 중에는 발병하지 않는 경우도 있으므로 충분조 건은 아니다. 감염된 사람의 저항력도 병원체의 독성만큼
발병 여부의 중요한 결정요인이다. 뿐만 아니라 병원체의 속성이 감염병의 역학적 양상을 결정하는 유일한 요인은 아니다. 예컨대 주민의 수가 소수인 격리된 지역사회에 독 성이 강한 바이러스나 세균이 침범하면 비교적 단기간에 대부분의 주민들이 사망하거나 면역을 획득하므로 더 이 상 전파되지 못하고 소멸할 것이다. 한편 인구규모가 크면 숙주의 수가 충분하므로 병원체가 전염을 이어갈 수 있다. 그리고 대규모 사회에서는 계층이 형성되게 마련이고, 이 에 따라서 질병의 분포가 계층별로 달라질 수 있다.

남태평양의 작은 섬나라인 Nauru 국민의 제 2 형 당뇨병 의 유병률 변화는 사회경제적 여건과 당뇨병의 연관성을 보여 주는 좋은 사례이다[38]. 제2차 세계대전 이전에는 이 나라 국민들의 주된 생계수단이 체력과 에너지 소모가 많 은 어업과 생계형 농업이어서 강도 높은 육체노동이 보편 적이었고, 식품이 부족한 경우가 많았다. 그러나 종전 후에 는 외국기업들의 인(燐) 광산 개발, 운영에 따라 소득수준 이 크게 증가하여 수입식품 위주로 식생활이 변화하고 신 체활동의 감소로 당뇨병이 대폭 증가하는 현상이 나타났 었다. 1950 년에는 55-64세 인구의 2/3가 당뇨병 환자여서 부 유한 국가로서는 예외적으로 수명이 짧았다. 그러나 당뇨 병에 의한 사망률의 증가와 수명의 단축으로 인해서 당뇨 병에 대한 감수성 관련 유전자의 인구분포가 변하여 1970 년대 중반에는 당 부하시험 이상자가 $21 \%$ 였으나, 1980 년대 후반에는 그 비율이 절반으로 감소했다.

$\mathrm{Nauru}$ 에서 관찰된 당뇨병의 역학적 변화를 유전자 수준 에서 설명하는 가설('thrifty genotype hypothesis')이 있다[40] 식량사정이 불안정해서 굶주림을 피할 수 없는 기간이 빈 번한 상황에서는, 음식을 넉넉히 먹을 수 있을 때 기근에 대 비하여 영양분을 체내에 비축할 필요가 있었으므로 섭취 한 후에 신속하게 지방으로 변환하는 기제가 작동했다는 것이다. 이러한 기제를 규율하는 유전자가 음식물이 풍부 해진 후에는 비만과 당뇨병을 발생시키는 방향으로 작용 했으리라는 추론이다. 이 가설이 맞는다면 사회적 요인들 이 유전자형과의 상호작용을 통해서 인구집단의 건강상태 와 질병의 분포에 영향을 미칠 수 있다고 말할 수 있겠다.

미국에서는 흑인이 백인에 비하여 당뇨병과 고혈압 유병 률이 2-3배 높았으나, 카리브해 지역에 거주하는 흑인의 유 병률은 미국이나 영국의 흑인에 비하여 $1 / 2-1 / 5$ 로 낮았다. 이는 미국에서 관찰되는 인종간의 건강상태 격차가 유전자 형 등의 생물학적 요인에 기인하기보다는 그들이 처해 있는 사회적 맥락의 차이와상관이 있을 가능성을 시사한다[41].

미국 University of Chicago의 Center for Interdisciplinary Health Disparities Research는 사회적 요인들이 질병을 발생시 키는 기제에 대하여 하향적 발병원인 모형('downward causal model') 또는 계층적 발병원인 모형('multilevel causal model') 
을 제시하였다[33]. 미국에서는 흑인여성들의 유방암으로 인한 사망률이 백인여성들에 비해서 높은데, 그들은 이와 같은 차이에 대한 연구를 통하여 특정 사회환경이 어떻게 질병발생에 작용하는지 이 모형으로 설명할 수 있음을 예시 하였다. 모형의 내용을 요약하면 가장 상층의 사회경제적 환경요인으로부터 시작하여 다음 수준의 계층들로 이어지 는 하향적 연쇄작용에 의하여 사회심리적 요인, 생물학적 반응 및 유방암 발병에까지 이르게 된다는 것이다. 각 계층 의 요인들은 상위계층 요인들의 규율 또는 제약 아래 작용 하며, 하층으로부터의 환류도 가능하다는 것이다.

지금까지 사회적 요인에 의한 발병에 관하여 몇 가지 실 증적 자료들을 살펴보았다. 이 자료들은 사회적 환경요인 과 건강이나 질병의 관계에 대한 심층적 이해를 위해서는 생의학적 지식, 방법 및 기술과 연계해서 연구하는 노력이 필요함을 시사한다. 그리고 이러한 연구들을 통해서 사회 의학 지식을 체계적으로 축적해 갈 수 있을 것이다[38].

\section{한국 사회의학의 실상}

일본 의학이 유럽 의학과 교류가 있었음을 고려하면 일 제 시대에도 사회의학이 알려졌을 개연성이 있다. 1920년 에 발간된 개벽 제 1 호에 게재된 “위생안(衛生眼)으로 본 이 대해독(二大害毒)”이라는 제목의 논설에서 필자인 의사 (醫師) 유홍종이 사회의학이라는 용어를 사용했으며 [42], 이 시기의 신문 기사 등에도 사회의학이라는 어휘가 등장 한다. 그러나 사회의학이 실제로나 학문으로서 얼마나 깊 이, 체계적으로 다루어졌는지에 대해서는 기록을 찾아볼 수 없었다.

해방 이후에도 사회의학이란 용어가 거의 사용되지 않 았다. 한국의 의학 발전에 주된 동력이 된 것은 1950년대부 터 활발해진 미국 의학과의 교류였는데, 앞서 언급한 바와 같이 사회의학은 미국 의학계가 기피하던 용어였고, 1950 년대 초반부터 얼마 동안은 특히 심하게 금기시했었기 때 문에 소개되지 않았던 것 같다. 그러나 사회적 요인을 연구 변수의 일부로 고려한 조사 자료를 이용한 논문들이 제목 에 “사회의학적 조사 연구” 등으로 사회의학이란 표현을 사용하는 경우는 있었다(근래에는 의사들이 갖춰야 할 인 문학이나 사회과학에 대한 지식과 소양의 배양을 위한 의 과대학 교육과 관련해서 발간된 저술로 "사회의학" [43], "사 회의학 교육 과정 개발 연구” [44] 등이 있으나 그 내용은 지 금까지 기술한 국제적으로 통용되는 사회의학의 개념과는 거리가 있으며, 따라서 논외로 해도 무방할 것이다.).

한국에서 사회의학이 대학의 공식 조직 및 교과목의 명 칭으로 사용된 것은 한림대학교가 1984년 사회의학연구소 를 설립하고, 1985 년 의과대학에 사회의학교실을 설치한
것이 처음이며, 이후에 추가로 2 개 의과대학이 사회의학교 실을 설치하였다. 이들 교실도 영어 명칭은 Department of Social and Preventive Medicine으로 표기하면서도 사회의학 이란 명칭을 사용하고 있다. 그 이유로 두 가지를 들고 있 다. 첫째는 예방의 원천적 지식과 기술은 다양한 전문 과목 에서 연구, 개발되며, 개인 대상 예방 서비스의 대부분은 다 수의 임상의학 과목에서 실행되므로 Stevens [45]가 지적했 듯이 예방은 의학 전반의 목적과 과제로서 특정 전문 분야 의 고유 영역이 될 수 없다는 견해이다. 둘째로는 한국 의과 대학의 예방의학 과목이 예방보다 훨씬 광범위한 내용의 주제들로 구성돼있는 점을 교실 명칭이 반영하지 못한다 는 것이다. 그러면 사회의학은 예방의학과 어떤 관계가 있 으며, '사회의학'이 '예방의학'이란 명칭의 이와 같은 문제 점들에 답하는 데 도움이 될까?

대한예방의학회가 펴낸 의과대학 학생들을 위한 교과서 에 의하면 "예방의학은 개인 또는 특정 인구집단의 건강과 안녕(well-being)을 보호, 유지, 증진하고 질병과 장애와 조 기사망을 예방하는 것을 전문으로 하는 의학의 한 분야이 다" [46]. 이 정의는 예방을 전문으로 하는 것과 개인뿐만 아 니라 인구집단도 대상으로 하는 것이 의학의 다른 전문분 야와 구별되는 예방의학의 고유성임을 함축하고 있다. 인 구집단의 건강과 질병에 대해서는 생의학적 모형만으로는 설명할 수 없는 문제들이 많으며 $[47,48]$. 사회의 제반 요소 들이 구성원들의 건강상태 및 보건의료체계와 어떤 관계 가 있는지에 대한 이해가 필요하다. 사회의학은 예방의학 과 이러한 개념 틀을 공유하고 있으며, 집단을 대상으로 한 다는 예방의학의 고유성과 정체성에 부합하는 용어라고 말할 수 있다. 미국에서 예방의학, 사회의학 및 지역사회의 학이 구분 없이 사용됐던 것은 이와 같은 개념적 공통점에 근거했을 것이다[49]. 한국 예방의학과 사회의학이 개념적 으로 공통된 부분이 있다는 것은 양자의 구체적 내용도 부 분적으로는 동일할 가능성을 뜻한다.

한국 예방의학과 사회의학의 내용적 관련성을 단편적으 로나마 구체적으로 살피기로 한다. 앞에서 언급한 대한예 방의학회가 펴낸 교과서에 포함된 주제들이 한국 예방의 학의 주된 내용이라고 볼 수 있다. 이 교과서는 주제를 제 1 편 건강과 질병, 제 2 편 역학과 그 응용, 제 3 편 환경과 건강 및 제 4 편 보건의료와 건강관리로 대별하여 저술하고 있다. 제 1 편에서 예방의학과 공중보건학 관련 개념을 정리하면 서 사회경제적 요인, 문화적 요인, 정치적 요인 등도 건강과 질병의 결정요인으로 들고 있는 것은 사회의학의 기본 개 념과 일치하는 시각이다. 제 2 편의 역학은 예방의학뿐 아니 라 사회의학을 포함한 모든 의학 분야의 방법론이며, 얼핏 순수 생의학적 문제로 보이는 각종 질환의 역학적 양상에 도 사회경제적 요인들이 중요한 변수로 작용한다. 제 3 편에 


\section{Journal of}

서 다루는 환경오염 및 직업성 질환 등의 이해와 해결에서 도 사회적, 경제적 여건요인들을 고려해야 한다. 그리고 제 4편의 주제인 보건의료체계, 의료보장, 지역사회보건 등은 사회 구성원의 건강 증진과 질병관리를 위한 제도적 장치 이고 정책수단이다. 이상의 몇 가지 선별적, 단편적 관찰로 도 한국의 예방의학은 사회의학의 내용을 내포하고 있음 을알수 있다.

요약하면 한국에서는 사회의학이란 용어를 극히 일부에 서만 사용하고 있으나, 그 내용은 의과대학의 예방의학 교 과 과정에 상당 부분 도입된 상태이다. 이러한 내용적 수용 은 사회의학의 개념과 원리에 대한 학계의 논의와 이해에 근거해서 이루어진 것이 아니라는 점에서 사회의학의 의 의와 가치를 전달하는 데 한계가 있다. 상황이 이러하므로 예방의학과 사회의학의 연계관계를 체계화하고, 그 내용 에 대한 학계와 관련 분야의 이해를 넓히는 노력이 필요하 다. 의과대학 예방의학 과목의 명칭을 많은 나라에서처럼 예방사회의학(preventive and social medicine)으로 변경하는 방안이 구체적 접근의 하나가 되겠다. 그리고 변경된 명칭 에 부합하도록 내용을 조정하고 보완하면 예방의학과 사 회의학의 학문적, 실천적 정체성을 정립하는 데도 도움이 될 것이다.

\section{요약 및 결론}

건강의 사회적 결정요인에 대한 관심의 증대가 근래의 국제적 동향이고, 유럽의 많은 의과대학들이 사회의학을 교과목으로 개설하고 있으며, 미국에서도 일부 대학들이 사회의학이 포함된 명칭의 department를 설치하고 있다. 이 러한 사실들은 사회의학이 분명히 의학의 한 전문분야임 을 적시한다. 그러나 사회의학은 한국 의학계에서는 거의 사용되지 않는 용어이다. 이와 같은 상황을 고려하여 이 논 문의 목적으로 두 가지를 설정하였다. 1) 사회의학의 기원 과 진화에 대하여 기술함으로써 한국 의학계의 사회의학 에 대한 이해를 돕는다. 2) 한국 사회의학의 실상을 간략히 기술하고, 발전을 위한 의제를 제시한다.

사회적, 경제적 여건이 건강, 질병 및 의료서비스에 미치 는 영향이 심대하며, 따라서 그에 대한 과학적 연구가 필요 하다는 것이 사회의학의 핵심적 개념에 속한다. 건강과 사 회적 요인들의 관계에 대한 관심은 18 세기에 시작되었으 나 사회의학이란 용어가 처음 쓰인 것은 프랑스에서 2월혁 명이 있었던 1848년 Jules Guérin에 의해서였다. 같은 해에 독일에서도 Rudolf Virchow 등의 보건의료개혁가들이 사회 의학을 창시하였다.

프랑스와 독일에서 창시된 사회의학은 유럽의 여러 나 라 등으로 확산되며 발전해왔다. 제 2 차 대전 종전 후에는
미국에서도 논의가 활발했으나 'social medicine'이 'socialized medicine'과 어감이 비슷하고 국가관리 의료체계를 함 의한다고 보아서 의료계가 기피하는 용어가 됐으며, 이러 한 기피경향은 1950 년대 초반에 미국을 휩쓴 공산주의자 색출 열풍인 매카시즘 때문에 더 심해졌다. 사회의학은 이 처럼 미국 의학계가 기피하던 용어였기 때문에 미국 의학 과의 교류를 통해서 발전이 시작된 한국 의학계에는 소개 되지 못했을 것이다.

예방의학은 건강과 질병문제를 다룸에 있어서 개인뿐만 아니라 인구집단도 대상으로 한다. 인구집단의 문제는 그 것이 무엇이든 이해하고 해결하려면 사회 차원의 시각과 접근을 요하는 측면이 있다. 그러므로 집단의 건강과 질병 문제는 생물학적 현상임과 동시에 사회현상임을 명시적으 로 인식하는 바탕 위에서 결정요인을 밝히고 해결방안을 찾아야 한다는 것이 사회의학적 시각이다.

한국에서는 사회의학이란 용어를 극히 일부에서만 사용 하고 있으나, 그 내용은 예방의학 교과 과정에 상당 부분 도 입된 상태이다. 이러한 내용적 수용은 사회의학의 개념과 원리에 대한 학계의 논의와 이해에 근거해서 이루어진 것 이 아니라는 점에서 사회의학의 의의와 가치의 전달에 한 계가 있다. 그러므로 예방의학과 사회의학의 연계관계를 분명히 이해하고 체계화하는 노력이 필요하다. 구체적 접 근으로는 의과대학 예방의학 과목의 명칭을 많은 나라에 서처럼 예방사회의학으로 변경하는 방안을 생각할 수 있 다. 그리고 변경된 명칭에 부합하도록 내용을 조정하고 보 완하면 예방의학과 사회의학에 대한 의학계와 관련 분야 의 이해를 넓히는 한편, 두 분야의 학문적, 실천적 정체성을 정립하는 데도 도움이 될 것이다.

\section{감사의 글}

이 논문은 2014년 11월 26일 한림대학교 사회의학연구소 가 개최한 학술집담회에서 발표한 “사회의학 개관"을 바탕 으로 삼았다. 발표문에 대하여 유익한 논평을 해준 학술집 담회 참석자들에게 감사드린다.

\section{참고문헌}

1. Dusek T, Bates T. Analysis of European medical schools' teaching programs. Croat Med J 2003;44(1):26-31.

2. Henderson GE, King NM, Strauss RP, Estroff SE, Churchill LR, editors. The social medicine reader. Durham: Duke University Press; 1997.

3. King NM, Churchill LR, Estroff SE, Henderson GE, Oberlander J, editors. The social medicine reader, 2nd ed., vol. 1: patients, 
doctors, and illness. Durham: Duke University Press; 2005.

4. Henderson GE, Estroff SE, Churchill LR, King NM, Oberlander J, Strauss RP, editors. The social medicine reader, 2nd ed., vol. 2: social and cultural contributions to health, difference, and inequality. Durham: Duke University Press; 2005.

5. Oberlander J, Churchill LR, Estroff SE, Henderson GE, King NM, Strauss RP, editors. The social medicine reader, 2nd ed., vol. 3: health policy, markets, and medicine. Durham: Duke University Press; 2005.

6. Lee JC. The development of German social medicine in the nineteenth century. Uisahak 1994;3(1):20-29 (Korean).

7. Porter D. How did social medicine evolve, and where is it heading? PLoS Med 2006;3(10):e399.

8. Rosen G. The evolution of social medicine. In: Freeman HE, Levine S, Reeder LG, editors. Handbook of medical sociology. 2nd ed. Englewood Cliffs: Prentice-Hall; 1972, p. 30-60.

9. Starr P. The social transformation of American medicine: the rise of a sovereign profession and the making of a vast industry. New York: Basic Books; 1982, p. 55.

10. Cockerham WC, Ritchey FJ. Dictionary of medical sociology. Westport: Greenwood Press; 1997, p. 119-120.

11. Hobson W. What is social medicine? Br Med J 1949;2(4619): 125-130.

12. Rosen $\mathrm{G}$. What is social medicine? a genetic analysis of the concept. Bull Hist Med 1947;21(5):674-733.

13. Taylor R, Rieger A. Rudolf Virchow on the typhus epidemic in Upper Silesia: an introduction and translation. Sociol Health Illn 1984;6(2):201-217.

14. Waitzkin $\mathrm{H}$. One and a half centuries of forgetting and rediscovering: Virchow's lasting contributions to social medicine. Soc Med 2006;1(1):5-10.

15. Anderson MR, Smith L, Sidel VW. What is social medicine? Mon Rev 2005;56(8):27-34.

16. Waitzkin H, Iriart C, Estrada A, Lamadrid S. Social medicine then and now: lessons from Latin America. Am J Public Health 2001;91(10):1592-1601.

17. Galdston I, editor. Social medicine: its derivations and objectives; the New York Academy of medicine institute on social medicine, 1947. New York: Commonwealth Fund; 1949.

18. Rosen G. Approaches to a concept of social medicine; a historical survey. Milbank Mem Fund Q 1948;26(1):7-21.

19. Morman ET. George Rosen, public health, and history. In: Rosen $\mathrm{G}$, editor. A history of public health. Expanded ed. Baltimore: Johns Hopkins University Press; 1993, p. Ixix-Ixxxviii.

20. Susser M. Teaching social medicine in the United States. Mil- bank Mem Fund Q 1966;44(4):389-413.

21. Madison DL. Introduction: where medicine and society meet. In: Social medicine, 20th anniversary report of the Department of Social Medicine, School of Medicine, University of North Carolina. Chapel Hill: University of North Carolina; 1998; p. 7-18.

22. Westerhaus M, Finnegan A, Haidar M, Kleinman A, Mukherjee $J$, Farmer P. The necessity of social medicine in medical education. Acad Med 2015;90(5):565-568.

23. Kasper J, Greene JA, Farmer PE, Jones DS. All health is global health, all medicine is social medicine: integrating the social sciences into the preclinical curriculum. Acad Med 2016;91(5): 628-632.

24. Social Medicine Consortium. Conference 2016: reimagining social medicine [cited 2016 May 1]. Available from: http:// www.socialmedicineconsortium.org/conferencedetails/.

25. Pemberton J. Origins and early history of the Society for Social Medicine in the UK and Ireland. J Epidemiol Community Health 2002;56(5):342-346.

26. Society for Social Medicine. Constitution of the society; 2015 [cited 2016 May 1]. Available from: https://socsocmed.org.uk/ about/constitution/.

27. UNC School of Medicine. UNC social medicine [cited 2016 May 1]. Available from: http://www.med.unc.edu/socialmed.

28. Thakur HP, Pandit DD, Subramanian P. History of preventive and social medicine in India. J Postgrad Med 2001;47(4):283285.

29. Porter D. Transformations in social medicine. Lancet 1999;354 Suppl:SIV57.

30. Marmot M. Social determinants of health inequalities. Lancet 2005;365(9464):1099-1104.

31. Farmer PE, Nizeye B, Stulac S, Keshavjee S. Structural violence and clinical medicine. PLoS Med 2006;3(10):e449.

32. Syme SL. Reducing racial and social-class inequalities in health: the need for a new approach. Health Aff (Millwood) 2008;27(2):456-459.

33. Gehlert S, Sohmer D, Sacks T, Mininger C, McClintock M, Olopade 0 . Targeting health disparities: a model linking upstream determinants to downstream interventions. Health Aff (Millwood) 2008;27(2):339-349.

34. Braveman P, Egerter S, Williams DR. The social determinants of health: coming of age. Annu Rev Public Health 2011;32:381398.

35. World Health Organization. Health topics: social determinants of health [cited 2016 Apr 26]. Available from: http://who.int/ 
topics/social_determinants/en/.

36. Krieger N. A glossary for social epidemiology. J Epidemiol Community Health 2001;55(10):693-700.

37. Link BG, Phelan J. Social conditions as fundamental causes of disease. J Health Soc Behav 1995;Spec No:80-94.

38. Eisenberg L. Does social medicine still matter in an era of molecular medicine? J Urban Health 1999;76(2):164-175.

39. Holtz TH, Holmes SM, Stonington S, Eisenberg L. Health is still social: contemporary examples in the age of the genome. PLoS Med 2006;3(10):e419.

40. Neel JV. Diabetes mellitus: a "thrifty" genotype rendered detrimental by "progress"? Am J Hum Genet 1962;14:353-362.

41. Cruickshank JK, Mbanya JC, Wilks R, Balkau B, McFarlane-Anderson N, Forrester T. Sick genes, sick individuals or sick populations with chronic disease? The emergence of diabetes and high blood pressure in African-origin populations. Int J Epidemiol 2001;30(1):111-117.

42. Yoo HJ. Two major harms from the viewpoint of hygiene. Gae- byuk 1920;1:108-111 (Korean).

43. Jeon WT. Social medicine. Yonsei J Med Educ 2001;3(2):1-13 (Korean).

44. Chun WT, Kim S, Yang EB. A study on the development of social medicine curriculum. Korean J Med Educ 2001;13(2):201212 (Korean).

45. Stevens R. American medicine and the public interest. New Haven: Yale University Press; 1971, p. 330.

46. Korean Society for Preventive Medicine. Preventive medicine and public health. Rev. ed. Seoul: Gyechuk Munwhasa; 2011, p. 19 (Korean).

47. Rose G. Sick individuals and sick populations. Int J Epidemiol 1985;14(1):32-38.

48. Rose G. The strategy of preventive medicine. Oxford: Oxford University Press; 1992.

49. The distinction between public health and community/social/ preventive medicine. J Public Health Policy 1985;6(4):435-439. 